Jurnal Konstruksi Hukum | ISSN: XXXX | E-ISSN: XXXX

Vol. 1, No. 1, September 2020 Hal. 98-102| Available online at

https://www.ejournal.warmadewa.ac.id/index.php/jukonhum

DOI: https://doi.org/10.22225/jkh.1.1.2312.1-8

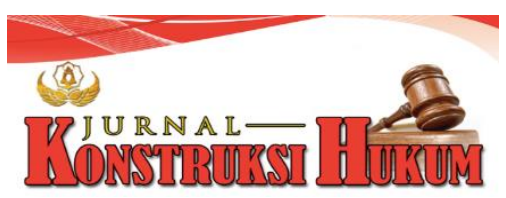

\title{
PENGGUNAAN MATERAI YANG DI SCAN PADA SURAT KUASA DI BAWAH TANGAN DALAM SUATU PERJANJIAN
}

\author{
Fika Pratiwi, I Ketut Sukadana, I Putu Gede Seputra \\ Universitas Warmadewa, Denpasar - Bali, Indonesia
}

\begin{abstract}
Abstrak
Penggunaan materai sangat penting untuk kelengkapan suatu dokumen di mana adanya materai secara tidak langsung menyatakan bahwasanya pemilik dokumen telah membayarkan pajak bea materai terhadap negara. Namun kini suatu dokumen dapat dikirimkan melalui berbagai media seperti email melalui proses scan pada suatu dokumen. Berdasarkan latar belakang tersebut, penelitian ini dilakukan dengan tujuan mendeskripsikan bagaimana pengaturan surat kuasa di bawah tangan dan perjanjian menurut Kitab Undang-Undang Hukum Perdata (KUH Perdata) serta bagaimana keabsahan surat kuasa di bawah tangan dengan materai scan yang dikirim melalui email. Metode penelitian yang digunakan adalah penelitian hukum normatif. Hasil penelitian ini menunjukkan bahwa pengaturan surat kuasa di bawah tangan dan perjanjian menurut Kitab Undang- Undang Hukum Perdata (KUH Perdata) telah diatur pada Pasal 1792 sampai dengan Pasal 1819 KUH Perdata. Pembuatan surat kuasa tentunya juga atas dasar perjanjian dari kedua belah pihak sebagaimana yang telah memenuhi syarat menurut KUH Perdata dalam Pasal 1320 tentang Syarat Sahnya Perjanjian. Selain itu, kekuatan surat kuasa di bawah tangan dengan menggunakan materai scan yang dikirim melalui email dapat dikatakan sah menurut hukum karena ada pembubuhan materai dalam suatu dokumen sebagaimana yang telah tercantum dalam Pasal 1 Ayat 6-7 Peraturan Pemerintah Nomor 82 Tahun 2012 tentang Informasi dan Transaksi Elektronik.
\end{abstract}

Kata Kunci : Email; Materai; Perjanjian; Scan; Surat Kuasa

\begin{abstract}
The use of stamp duty is very important for the completeness of a document where the stamp implicitly shows that the document owner has paid stamp duty tax to the state. However, now a document can be sent via various media such as email by scanning a document. Based on this background, this research was conducted with the aim of describing the regulation of a power of attorney under hand and an agreement letter according to the Civil Code and how the validity of the power of attorney under hand with a scanned stamp which then sent via email is. The research method used is normative legal research. The results of this study indicated that the arrangement of power of attorney under hand and an agreement letter according to the Civil Code has been regulated in Article 1792 to Article 1819 of the Civil Code. The power of attorney, of course, is also based on the agreement of the two parties as it has met the requirements according to the Civil Code in Article 1320 concerning the Terms of Legality of the Agreement. In addition, the power of attorney under hand using a scanned stamp sent via email can be said to be legal according to law because there is a stamp duty in a document as stated in Article 1 Paragraph 6-7 of Government Regulation Number 82 of 2012 concerning Information and Electronic Transactions.
\end{abstract}

Keywords: Email; Stamp Duty; Agreement; Scan; Power of Attorney

I. PENDAHULUAN

Sebagai mahluk sosial seorang manusia harus hidup bermasyarakat dan berinteraksi dengan sekitarnya untuk memenuhi kebutuhan hidupnya sehari-hari, hal ini terlepas dari pengaruh orang lain. (Murdiatmoko, 2007) Manusia hidup secara bersama-sama karena saling membutuhkan satu sama lain. Sebagai mahluk individu manusia harus saling bergaul untuk mempertahankan hidupnya, karena hal tersebutlah Aristoteles menyebut manusia sebagai zoon poloticon, yang berarti manusia ditakdirkan sebagai mahluk sosial jadi dikodratkan untuk hidup bermasyarakat (Kansil, 2005). 
Suatu negara memiliki konstitusi sebagai satu dokumen yang memuat kesepakatan yang telah dirumuskan oleh para pendiri Negara. Hal ini memuat apa-apa yang menjadi tujuan Negara itu sendiri. Atas dasar pemikiran tersebutlah Negara didirikan, cabang-cabang kekuasaan Negara dibentuk, serta bagaimana hubungan lembaga-lembaga Negara itu satu sama lain serta hubungan Negara dengan rakyatnya. Untuk dapat hidup bermasyarakat yang diwadahi oleh suatu Negara yang memiliki suatu sistem hukum dan lalu dapat disebut sebagai Negara hukum yang berdaulat, maka istilah Negara hukum secara konstitusional telah disebutkan pada UUD NRI 1945. Penggunaan istilah Negara hukum mempunyai perbedaan antara sesudah dilakukan amandemen dan sebelum dilakukan amandemen.

Untuk mewujudkan Negara hukum salah satunya diperlukan perangkat hukum yang digunakan untuk mengatur keseimbangan dan keadilan di segala bidang kehidupan manusia. Terlebih jika dilihat dari cara berinteraksi dengan sesamanya, dalam memenuhi kebutuhan hidupnya setidaknya manusia dalam hidup bermasyarakat memerlukan kerjasama antara satu orang dengan orang atau kelompok lainnya. Namun ada kalanya interaksi tersebut menimbulkan perbedaan pendapat yang lalu memunculkan suatu permasalahan, terlebih jika dilihat dalam era revolusi industri 4.0. Ketika informasi semakin cepat mengalir, manusia dituntut untuk cepat pula memenuhi kebutuhannya. Hal ini juga menimbulkan kemungkinan terjadinya konflik. Kesalahpahaman atau perbedaan kepentingan antara individu juga semakin besar yang tidak jarang menimbulkan peristiwa dan permasalahan hukum. Atas dasar tersebutlah lalu dibentuk suatu aturan atau norma hukum di mana dalam hal ini merupakan aturan tertulis.

Di dalam buku III Kitab Undang- Undang Hukum Perdata (selanjutnya disebut KUH Perdata) mengatur tentang perikatan (verbintenis). Maksud penggunaan kata 'perikatan' disini dapat lebih luas dari pada kata 'perjanjian' dan Buku IV mengenai daluarsa. Hukum tentang pembuktian tidak saja diatur dalam hukum acara (Herzine Indonesisch Reglement/HIR) namun juga telah diatur di dalam Kitab Undang-undang Hukum Perdata. Surat kuasa merupakan hal yang dimuat dalam Buku III karena termasuk bagian dari perikatan di mana di atur dalam Kitab Undang-Undang Hukum Perdata (KUH Perdata) pada Bab XVI Pasal 1792 Kitab Undang-Undang Hukum Perdata (KUH Perdata) yaitu dijelaskan mengenai pengertian kuasa di mana kuasa merupakan persetujuan yang isinya pemberian kekuatan untuk orang lain dalam rangka melakukan tindakan hukum atas nama orang yang memberikan kuasa.

Para Pihak dalam Perjanjian kuasa yang dimaksud dalam Pasal 1792 tersebut adalah Pemberi Kuasa atau lastgever (instruction, mandate) dan Penerima kuasa / lasthebber (mandatory). Sedangkan perjanjian merujuk Pasal 1313 KUH Perdata yang memberi rumusan tentang kontrak atau perjanjian yaitu di mana perjanjian ialah suatu perbuatan yang mengikat antara satu orang kepada orang/badan hukum lainnya.

Seiring dengan perkembangan zaman kini perjanjian dapat dilakukan dengan media online, tetapi prinsip utamanya tetaplah adanya kesepakatan di antara para pihak yang bersangkutan (agreement). Meskipun secara prinsip bentuk kesepakatan di dalam transaksi elektronik secara umum adalah sama, namun dalam bentuknya mempunyai perbedaan. Bertolak dari perbedaan bentuk maka diaturlah dengan sebutan "variation by agreement". Di dalam konsep perjanjian, kebebasan menentukan kesepakatan ini ialah bagian dari lingkup proses offer and acceptance (penawaran dan penerimaan) di mana perbedaan bentuknya harus diakomodir oleh hukum itu sendiri. Dalam e-contract, bentuk offer and acceptance dilakukan dengan menggunakan jaringan elektronik, atau dikenal dengan sebutan electronic data interchange (EDI) (Dawud, 2018). Ada kaitannya dengan kekeliruan pemahaman tentang tanda tangan digital yang dikatakan sebagai tanda tangan konvensional yang didigitalisasi dengan proses scan pada konteks perjanjian elektronik harus mengacu kepada rumusan pasal 1 angka 12 Undang- Undang No. 19 Tahun 2016-ITE, yang menjelaskan mengenai tanda tangan elektronik yang terdiri dari informasi di media elektronik atau digital, terasosiasi serta terikat dengan informasi elektronik lain yang nantinya digunakan sebagai alat verifikasi dan autentikasi.

Beberapa hal juga dapat membedakan antara tanda tangan elektronik dengan dilakukannya proses scan di mana scan merupakan suatu proses untuk menduplikat objek-objek pada suatu dokumen yang dalam hal ini ialah surat kuasa untuk bisa dikirim melalui berbagai media karena berbagai kendala antara 
para pemangku kepentingan (Silam, 2018). Terkait dengan hal tersebut, maka dengan perkembangan zaman pulalah banyak kendala ditemukan, salah satunya dalam surat kuasa yang lalu dapat dipermasalahkan karena jarak yang jauh di antara para pihak yang melakukan perikatan, di mana salah satu pihak tinggal di luar negeri yang lalu istrinya akan meminjam uang pada suatu bank dan tentunya memerlukan persetujuan suami. Jarak yang terlampau jauh akhirnya mengharuskan sang istri untuk mengirimkan surat kuasa yang telah di-scan lengkap bersama materai kepada suami melalui electronic mail (Email) untuk ditandatagani dan dikirim kembali dengan surat kuasa yang sudah tertera tandatangan suami lengkap (Makarim, 2015).

Apabila dikutip dari Undang-Undang Permateraian yakni Undang-Undang No. 13 tahun 1985, suatu perjanjian yang sah haruslah memiliki beban materai sebagai pemenuhan pajak kepada Negara. Untuk memberi kepastian sesuai ketentuan yang telah ditetapkan bahwa memang benar surat kuasa tersebut merupakan surat kuasa yang sah dan memenuhi unsur-unsur dari perjanjian itu sendiri.

Dalam permasalahan tersebut diperkirakan terjadinya suatu pertentangan atau kekaburan norma sehingga dari unsur-unsur tersebut ditemukan adanya perbedaan pemanfaatan perjanjian yang nantinya dapat meresahkan. Berdasarkan hal tersebut penelitian ini dilakukan dengan tujuan mendeskripsikan bagaimana pengaturan surat kuasa di bawah tangan dan perjanjian menurut Kitab Undang-Undang Hukum Perdata (KUH Perdata) dan bagaimana keabsahan surat kuasa di bawah tangan dengan materai scan yang dikirim melalui email.

\section{METODE PENELITIAN}

Penelitian ini didesain dengan menggunakan metode penelitian hukum normatif. Penelitian ini ini mengacu pada kajian hukum yang tertulis yang diperoleh dari berbagai aspek hukum. Namun penelitian ini tidak mengkaji aspek hukum terapan atau implementasinya dalam kehidupan masyarakat terkait judul. Bahan-bahan hukum yang digunakan adalah bahan hukum primer, bahan hukum sekunder, dan bahan hukum tersier. Teknik pengumpulan bahan hukum yang dipergunakan yakni dengan cara mencatat, meresume dan penelusuran kepustakaan dari berbagai buku-buku, literatur, makalah yang menunjang penelitian, perpustakaan, dan jurnal-jurnal hukum yang berkaitan dengan masalah yang diangkat dalam proposal ini.

Undang-Undang dan Peraturan Pemerintah didapatkan dari sumber hukum seperti buku-buku hukum yang telah dikaji. Sedangkan Penyajian dalam penulisan bahan hukum yang telah diperoleh ini, dianalisa secara interpretasi yaitu dengan memilih bahan hukum yang kualitasnya dapat menjawab permasalahan mengenai pelaksanaan dan hambatan dalam Jaringan Dokumentasi Dan Informasi Hukum (Soekanto \& Mamudji, 1995).

\section{HASIL DAN PEMBAHASAN}

\section{Pengaturan Surat Kuasa di Bawah Tangan dan Perjanjian Menurut Kitab Undang-Undang Hukum Perdata}

Pemberian kuasa merupakan perbuatan hukum yang berasal dari perjanjian yang sering kali dilakukan pada kehidupan bermasyarakat. Karena meliputi berbagai aspek, hal ini diatur dalam hukum tertulis yakni Kitab Undang- Undang Hukum Perdata (Lemek, 2010). Dalam bidang hukum materiil diatur pada buku III, Bab XVI, Pasal 1792 sampai dengan Pasal 1819 KUH Perdata, sedangkan dalam bidang hukum formil, diatur dalam Pasal 123 H.I.R (Pasal 147 R. Bg).

Sebagai sebuah kesepakatan bersama (perjanjian), surat kuasa didasarkan oleh ketentuan-ketentuan tentang syarat-syarat sahnya perjanjian menurut Pasal $1320 \mathrm{KUH}$ Perdata yaitu adanya kata sepakat (Pasal 1321-1328 KUH Perdata), kecakapan (Pasal 1329 - 1331 KUH Perdata), suatu hal tertentu (Pasal 1332 - 1334 KUH Perdata), dan suatu sebab yang halal (Pasal 1335 - 1337 KUH Perdata). Sifat kuasa adalah memiliki garansi kontrak yaitu memberikan batasan-batasan tanggung jawab pemberi kuasa hanya pada sebatas kekuasaan yang diberikannya kepada si penerima kuasa tersebut. Jika terjadi pelanggaran pada surat kuasa atau terjadi tindakan yang melenceng dari apa yang telah disepakati bersama, segala tindakan penerima kuasa merupakan tanggung jawab pribadi penerima kuasa (Sukandar, 2017). Surat kuasa dalam pasal 1792 KUH Perdata pengertian surat kuasa di mana lebih lanjut diatur dalam Pasal 1793 
KUH Perdata dijelaskan yang bahwasanya surat kuasa bisa diterima dan diberikan dalam bentuk akta umum, surat di bawah tangan atau bahkan dengan sepucuk surat atau lisan.

Penerimaan ataupun pemberian kuasa juga dapat terjadi secara diam-diam dan disimpulkan oleh pelaksanaan kuasa itu kepada yang diberi kuasa. Mengenai jenis pemberian kuasa telah diatur dalam Pasal 1795 KUH Perdata yakni dapat dibagi menjadi dua yaitu kuasa umum dan kuasa khusus. Pemberian kuasa secara khusus ialah surat kuasa yang diberikan oleh seseorang kepada orang lainnya yang dalam surat kuasa itu wajib disebutkan secara khusus surat kuasa tersebut dipergunakan untuk perbuatan hukum apa. Misalnya, surat kuasa dari seorang klien kepada advokat untuk mengajukan gugatan atas tindakan sewa-menyewa rumah kepada $\mathrm{A}$, atau surat kuasa dari seseorang kepada $\mathrm{B}$, misalnya khusus untuk menagih utang kepada C. Syarat yang paling penting dari surat kuasa khusus sesuai doktrin dan yurisprudensi tetap Mahkamah Agung Republik Indonesia adalah harus menyebutkan secara khusus perbuatan hukum apa yang dikehendaki oleh si pemberi kuasa tersebut (Lemek, 2010). Sedangkan Kuasa umum yaitu jenis surat kuasa yang menerangkan penerima kuasa atau yang dikuasakan diberikan kewenangan yang cukup luas untuk melakukan berbagai tindakan demi kepentingan pemberi kuasa itu sendiri. Karena hal tersebut yang diatur dalam surat kuasa yakni hal-hal yang bersifat umum dan luas (Jehani, 2007).

Adapun bentuk- bentuk pemberian kuasa dibagi menjadi beberapa macam yaitu (Maerisa, 2013):

1. Pemberian kuasa secara lisan ialah pemberian kuasa yang dibuat secara lisan/langsung oleh si pemberi kuasa kepada si penerima kuasa dimana si pemberian kuasa lisan tersebut biasanya terjadi disebabkan oleh adanya beberapa hal yang sangat mendesak yang sedang dialami oleh si pemberi kuasa untuk memberikan kuasa kepada si penerima kuasa itu sendiri.

2. Pemberian kuasa secara tertulis, ialah pemberian kuasa yang dimana telah direncanakan oleh si pemberi dan si penerima kuasa, pemberian kuasanya pun juga dibuat dengan cara tertulis (di bawah tangan) oleh para pihak yang bersangkutan.

3. Pemberian kuasa secara diam-diam merupakan yang disimpulkan dari pelaksanaan kuasa tersebut.

4. Bagian-bagian yang merupakan mekanisme pembuatan surat kuasa yang sah.

\section{Keabsahan Surat Kuasa di Bawah Tangan dengan Materai Scan yang Dikirim melalui Email}

Keabsahan surat kuasa di bawah tangan dengan materai scan lalu dikirim melalui email sebelum diatur dalam Undang-Undang No. 19 Tahun 2016 adapun Peraturan Pemerintah Nomor 82 Tahun 2012 tentang Informasi dan Transaksi Elektronik pernah diberlakukan untuk menciptakan dasar hukum bagi transaksi daring di seluruh Indonesia. Artinya, semua aktivitas yang berkaitan dengan internet atau elektronik wajib mengacu pada aturan tersebut. Salah satunya mengenai penggunaan alat bukti elektronik dalam perjanjian. Hal-hal yang dimaksud dengan alat bukti tersebut, meliputi dokumen dan informasi elektronik dalam Peraturan Pemerintah Nomor 82 Tahun 2012 tentang Informasi dan Transaksi Elektronik.

Masalah yang dikemukan dan diatur baik dalam UU ITE ataupun Peraturan Pemerintah mengenai ITE yang lama adalah hal yang berkaitan dengan masalah kekuatan dalam sistem pembuktian dari informasi, dokumen, dan tanda tangan elektronik bersama pembubuhan materai karena pada dasarnya penggunaan materi diwajibkan untuk suatu dokumen sebagai tanggungan pajak atas negara dan sebagai alat pembuktian yang sah. Namun dalam hal maraknya penggunaan sosial media kini surat kuasa yng sudah berisikan materai dapat di scan dan dikirim melalui email.

Surat kuasa antara para pihak yang dikirim melaui email memang tetap dinyatakan sah, namun dari pihak ketiga sebagai orang atau badan hukum tetap harus menerima surat kuasa asli sebagai arsip apabila terjadinya suatu sengketa. Jika hanya melalui pengiriman email saja, itu dinyatakan tidak memiliki kekuatan hukum tetap. Apalagi dalam media sosial sering terjadinya pembajakan (Hack) oleh berbagai pihak yang tentunya menimbulkan masalah baru dan dikhawatirkan dapat merugikan pihak ketiga sebagai orang/badan atau dapat disebut juga objek kerjasama/transaksi (Wawancara Dr. Nella Hasibuan O'Leary S.H., CN., MH., 10 Januari 2020). 


\section{SIMPULAN DAN SARAN}

\section{Simpulan}

Pengaturan surat kuasa di bawah tangan dan perjanjian menurut Kitab Undang- Undang Hukum Perdata (KUH Perdata) dalam hal ini telah diatur pada Pasal 1792 sampai dengan Pasal 1819 KUH Perdata. Pembuatan surat kuasa tentunya juga atas dasar perjanjian dari kedua belah pihak sebagaimana yang telah memenuhi syarat menurut KUH Perdata dalam Pasal 1320 tentang Syarat Sahnya Perjanjian. Selain daripada memenuhi syarat sahnya suatu perjanjian sebagaimana yang telah dijelaskan, surat kuasa dalam rangka pembuatannya yang dilakukan dengan di bawah tangan dapat diakui dan dikatakan sah di mata hukum sepanjang pembuatan surat kuasa tersebut memenuhi unsur-unsur surat kuasa, mekanisme pembuatan kuasa itu sendiri, dan perjanjian serta pembuatannya juga di hadapan pejabat yang berwewenang.

Kekuatan surat kuasa di bawah tangan dengan menggunakan materai scan yang dikirim melalui email dapat dikatakan sah menurut hukum, karena mengenai pembubuhan materai dalam suatu dokumen. Terkait dengan adanya cara scan dan dikirim melalui email maka dalam hal ini tetap dapat dikatakan sah menurut hukum dikarenakan sebagaimana yang telah tercantum dalam Pasal 1 Ayat 6-7 Peraturan Pemerintah Nomor 82 Tahun 2012 tentang Informasi dan Transaksi Elektronik disebutkan, meskipun dengan materai di scan, selama itu tidak bertentangan maka tetap dapat dipergunakan sebagai alat bukti sempurna di mata hukum. Namun meskipun di antara para pihak pembuat dan penerima kuasa dikatakan sah, acuan dari sahnya surat kuasa tersebut juga dapat diukur dari diterima atau tidaknya surat kuasa oleh pihak ketiga sebagai orang dan/badan hukum yang bersangkutan.

\section{Saran}

Pemerintah sebagai pencipta suatu produk hukum sebaiknya lebih memperhatikan masyarakat sebagai pemangku kepentingan dalam suatu media dokumen berbasis online. Materai merupakan pajak atas suatu dokumen. Apabila disalahgunakan, pelaku harus dikenakan sanksi perdata yang lebih tegas agar menimbulkan efek jera bagi setiap pelanggarnya.

Sedangkan saran untuk Masyarakat sebagai Warga Negara Indonesia (WNI) yang baik dan tentunya sebagai wajib pajak seharusnya lebih memperhatikan mengenai pembayaran pajak materai dalam suatu dokumen yang berkepentingan untuk pribadi maupun perusahaan. Oleh karena itu, penggunaan materai scan memang sebenarnya menjadi solusi tepat bagi para pemangku kepentingan misalnya WNI yang tinggal atau bekerja diluar negeri. Apalagi jika dilihat dari kapasitas era revolusi industry 4.0 ini, pengiriman dokumen melalui berbagai media sangat marak dan tentunya harus membuat masyarakat untuk lebih cermat dalam setiap pengiriman dokumen melalui media sosial apalagi jika terkait dengan pajak negara (materai).

\section{DAFTAR PUSTAKA}

Dawud, M. (2018). Mengenai Kontrak Elektronik Click Warp Agreement dan Tanda Tangan elektronik. Jehani, L. (2007). Panduan Khusus Membuat Perjanjian. Jakarta Selatan: Visimedia.

Kansil, C. S. T. (2005). Pengantar Ilmu Hukum dan Tata Hukum Indonesia (7th ed.). Jakarta: Balai Pustaka.

Lemek, J. (2010). Penuntun Membuat Gugatan. Jakarta: New Merah Putih.

Maerisa, E. A. (2013). Membuat Surat-Surat Bisnis dan Perjanjian. Jakarta: Visimedia.

Makarim, E. (2015). Keautentikan Dokumen Publik Elektronik dalam Administrasi Pemerintahan dan Pelayanan Publik. Jurnal Hukum Dan Pembangunan, 45(4), 508-571.

Murdiatmoko, J. (2007). Sosiologi Memahami dan Mengkaji Masyarakat. Bandung: Grafindo Media Pratama.

Silam, M. M. M. (2018). Pemindaian Secara Elektrik (E-Scanning) dalam Pengembangan Sistem Administrasi Modern. Administraus - Jurnal Ilmu Administrasi Dan Manajemen, 2(2), 151-174.

Soekanto, S., \& Mamudji, S. (1995). Penelitian Hukum Normatif: SuatuTinjauan Singkat. Jakarta: Rajawali Pers.

Sukandar, D. (2017). Panduan Membuat Kontrak Bisnis. Jakarta: Visimedia. 